\title{
Today's Learner, Preferences In Teaching Techniques
}

\author{
Vincent Agnello, Niagara University, USA \\ Bohdan Pikas, Niagara University, USA \\ Audrey J. Agnello, Niagara County Community College, USA \\ Anastasia Pikas, Niagara University, USA
}

\begin{abstract}
The computer age is here. Students are tuned in to the latest digital devices and methods available today. Most students are exposed to short messages with video enhancements. This gives rise to a student who gets frustrated and bored with the standard lecture technique of years past. To achieve a greater effectiveness and learning outcome in delivering a lecture and subsequent learning, the professor has to know and understand the changes that are occurring in today's learner. This paper presents findings of a study comparing the perceptions of first year freshmen business students' with upper class business students' perceptions as to how learning and assessment should occur in the classroom. The study also evaluates the differences between the various types of business majors.
\end{abstract}

Keywords: effectiveness of learning; effectiveness of assessment; today's learner; teaching delivery systems; students' teaching preferences; students' assessment preferences

\section{INTRODUCTION}

Dith increased focus on outcomes assessment by accreditation agencies, it is important that colleges of business identify and employ the most effective teaching strategies to maximize student learning. While there has been much research by our counterparts in Education, the question of whether the study of business is unique, or perhaps business majors themselves have specific learning preferences, should be explored. Do business majors find particular learning and teaching strategies more effective than others?

There are inherent difficulties when attempting to compare the effectiveness of learning methodologies. A focus on performance would necessitate that a variety of teaching techniques be used for a particular learning objective and then a uniform assessment be employed to measure and compare the efficacy of each method. This strategy, in itself, is fraught with variables that might render the results dubious. There are inherent differences in learning styles among students and which teaching methods they respond to best. The assessment itself might be the cause of lower performance for certain students more than others. Other variables that could potentially skew the results include motivation, locus of control, inherent intelligence or ability, and prior knowledge.

Given those difficulties, this study looks at which teaching and learning strategies business students prefer. Students' preferences are instructive, as they indicate their willingness to engage in the learning activity or task, which will affect learning outcomes. Karns, a marketing education researcher, makes this same observation in both his 1993 and 2005 studies, “...These data indicate students' willingness to engage in learning through various learning activities as well as their sense of an activity's contribution to their learning."

\section{REVIEW OF LITERATURE}

A review of existing literature demonstrates that surveying student perceptions is an accepted approach by marketing education researchers (Duke, 2002 and Karns, 1993, 2005). Karns work in 1993 indicated student preference for real-world learning activities, such as guest speakers, discussions and client projects. In 2005, Karns 
repeated the study but included a wider range of learning activities. His results confirmed marketing students' preferences for applied, "real-world" learning activities. Given the increased number of choices, preferred learning activities included field trips, guest speakers, film/videos, internships, and class discussions. The most effective learning activities as indicated by students included internships, class discussions and case analyses.

While studies on various teaching methods abound, very few focus on their implementation in business courses. The following are the few studies identified. In assessing both students and faculty perceptions of PowerPoint, James, Burke and Hutchins (2006) found that while students held less favorable views than did faculty of its influence on student learning, both groups agreed that PowerPoint is superior to straight lecture for key point emphasis, information recall, note taking, cognitive learning and facilitating discussion. In facilitating student relationships ("getting to know one another"), however, lecture is more effective than PowerPoint.

Betts and Knaus (2006) evaluated student perceptions of a management simulation game in a capstone business policy and strategy course. Students enjoyed the "real world" challenge and observing how their decisions impacted results. They also enjoyed the competition and teamwork it fostered. Negative aspects identified included students' reports that initially the game was very difficult to understand and that they did not have sufficient practice rounds. They were also concerned about the significant weight (30\%) that game performance had upon their final grade.

Clarke, Flaherty and Mottner (2001) assessed student perceptions of 14 technology learning tools in an attempt to determine which students felt favorably influenced their learning. This was accomplished through a survey administered at the conclusion of an Internet marketing class $(\mathrm{N}=114)$. Nine technology learning tools received high positive student ratings: instructor home page, Internet project, online homework assignments, online lecture outlines, online syllabus, online student roster page, online student grade page, web page project and technology lectures. One might argue that many of these "tools" really represent features of a course management system and not essentially learning activities. The technology tools which had no positive influence on student learning as perceived by students were: FAQ page, lab-only classes, online readings, chat rooms and electronic discussion groups.

In assessing student attitudes toward group work, Gottschall and Garcia-Bayonas (2008) surveyed 291 education, math and business administration major using a five-point Likert scale and an Analysis of Variance (ANOVA) to detect differences between the majors. They found that Education majors had a statistically significant more positive or neutral attitude toward group work than did Business Administration majors (54.5\% negative attitude). In fact, $63 \%$ of the math majors and $47.3 \%$ of the business administration majors, as opposed to $34.5 \%$ of the education majors, preferred to work alone. The primary concern for education and math majors was "free riding," whereas business majors' main concern was difficulty in coordinating group members' schedules. It should be mentioned that the response rate to the survey was quite low $(23.7 \%, \mathrm{~N}=291)$, and that the number responding was primarily education $(\mathrm{N}=206)$, with business administration at 55 respondents and math at 27 respondents.

Giordano and Rochford (2005), in an attempt to understand a decline in business education enrollment, surveyed the learning styles of 503 freshman business majors and found that $94 \%$ were analytic learners (moving from detail to general concept). High achievers exhibited more analytic tendencies, whereas lower achievers were more global in orientation (preferring the concept first, then details). In addition, business students have certain environmental preferences. The majority of business students prefer bright light, a quiet learning environment, and informal seating.

\section{METHOD}

The objective of this study was to look at four factors as perceived by business majors regarding their business courses. In particular the study focused on:

1. With what learning activity do students perceive they learn best? (e.g. in-class problems, term papers, oral presentations, simulations, role playing, etc.) 
2. What method of instructional delivery do students perceive is best for them? (PowerPoint, video, lecture, online course management system)

3. What methods of testing and assessment do students perceive as best reflects what they learned? (essay, take home, papers, oral presentations)

4. What class delivery time do students perceive is the most effective for their learning? (morning, afternoon, evening)

This study also analyzed whether student answers on learning effectiveness differed by majors, by class year, or by gender. The hypothesis was that student responses would vary by class year, majors, and gender. The data were collected at a private Catholic university in upstate New York with a business school accredited by AACSB International. Information was gathered through the use of a questionnaire administered to 387 business majors using a process that insured responding student anonymity. A Likert scale (1-5) was employed, requesting preferences on a variety of topics. Of the 387 students surveyed, 206 were males and 181 were females or a $53.2 \%$ to $46.8 \%$ split. According to the university's institutional data for the College of Business, the breakdown is 58.8\% males and $41.2 \%$ females. The survey results reflect a $5.6 \%$ variance in favor of men. All of the other demographics closely reflect the college's actual population. The breakdown of the respondents by class year and by major or concentration is shown in Tables 1 and 2:

Table 1: Respondent Demographics by Class Level

\begin{tabular}{lc}
\hline Class & \multicolumn{1}{c}{ Number } \\
Freshmen & 139 \\
Sophomore & 89 \\
Junior & 91 \\
Senior & 68 \\
& \\
& \\
Table 2: Respondent Demographics by Major & $\underline{\text { Number }}$ \\
\hline Major/Concentration & 115 \\
Accounting & 101 \\
Marketing & 96 \\
Management & 9 \\
Finance & 14 \\
Economics & 32
\end{tabular}

The results are summarized into several categories. The first part will analyze perceptions of business students overall. The second part will look at differences in their perceptions based on class year. The last part will explore differences and similarities by major and by gender.

\section{OVERALL FINDINGS}

The ultimate objective of education is student learning. Most recent efforts have centered on methods of content delivery. Perhaps more emphasis should be placed on how students learn best. From the students' perspective, working on real-life, hands-on projects were ranked most effective for learning. Least effective were oral presentations and working in small groups on term papers with a group grade. Students thought PowerPoint, videos, straight lectures, and course management support systems were all effective in their learning process and data collected reveals only a slightly favorable edge toward videos and PowerPoint.

Students perceived take-home tests as the best method of assessment for effectiveness in determining what they learned. This was followed closely by objective tests. Surprisingly, essay tests and oral presentations were perceived as the least effective method of assessing what they learned. Nearly half of the students ranked them as ineffective. 
Colleges and universities have a tremendous amount of money invested in bricks and mortar and are always seeking ways to maximize their return. Registrars now schedule courses from early morning straight through late evening classes. In some cases, certain required courses are scheduled for early morning and late evening to insure that classrooms are full during those times; but are all class times as effective in the learning process? In terms of learning effectiveness, 54\% of the students preferred classes in the afternoon compared to $42 \%$ in the morning. Only $4 \%$ selected evening classes as the most effective learning time for courses, but as with most universities, students are forced to attend evening classes to maximize classroom utilization. Table 3 illustrates the student response to specific delivery times. The survey was structured to have students first select their favorite time period and then select their optimum class time within that period. The morning students selected the 10:00 a.m. class period as best for them and the afternoon students selected 1:00 p.m. The few who opted for evening classes were given a choice of selecting between a three hour, one night per week course and a course that meets twice per week.

Table 3: Table of Class Time Preferences of Students

\begin{tabular}{llll}
\hline 8:00 a.m. $-2 \%$ & 1:00 p.m. $-62 \%$ & Two 11/2 hour classes $-58 \%$ & morning $-42 \%$ \\
9:00 a.m. $-30 \%$ & $2: 00$ p.m. $-28 \%$ & One 3 hour class $-42 \%$ & afternoon - 54\% \\
10:00 a.m. $-41 \%$ & $3: 00$ p.m. $-6 \%$ & & evening $-4 \%$ \\
11:00 a.m. $-22 \%$ & $4: 00$ p.m. $-3 \%$ & & \\
12:00 p.m. $-5 \%$ & $5: 00$ p.m. $-1 \%$ & &
\end{tabular}

Percentages represent percent of students selecting a particular class time within their first choice preference. Each column total reflects $100 \%$.

\section{CLASS VARIATIONS}

All class groups ranked real life hands-on learning and participating in-class discussions as the most effective for their learning. This is exactly what the Karns studies found (1993, 2005). Analysis of freshmen versus seniors did reveal differences in their preferences (Tables 4 and 5). Freshman preferred working in small groups, while seniors preferred working alone. While oral presentations were ranked ineffective by all groups, seniors were the most strongly opposed to them. Freshmen through seniors all ranked Power Points and videos as effective learning tools. Interestingly, the freshmen leaned toward use of PowerPoint presentations, while seniors had a greater appreciation for videos. All classes thought that take-home tests and objective tests best assessed what they learned. While essay tests were ranked much lower by all classes, there was a $10 \%$ higher ranking for their effectiveness by seniors when compared to freshman responses.

Table 4: Perception Variation by Freshman Class

\begin{tabular}{|c|c|c|c|c|c|c|}
\hline \multicolumn{7}{|c|}{$\begin{array}{l}\text { (Key to table headings: } \mathrm{NE}=\text { Not Effective, } \mathrm{NE}-\mathrm{N}=\text { Not Effective }- \text { Neutral, } \mathrm{N}=\text { Neutral, } \\
\qquad \mathrm{E}=\text { Effective, } \mathrm{VE}=\text { Very effective, NA = Not Applicable.) }\end{array}$} \\
\hline Effectiveness Of Learning & $\underline{\mathbf{N E}}$ & $\underline{\mathrm{NE}-\mathrm{N}}$ & $\underline{\mathbf{N}}$ & $\underline{\mathbf{E}}$ & $\underline{\mathbf{V E}}$ & $\underline{\mathbf{N A}}$ \\
\hline 1 Working in small groups for in-class problems & $6 \%$ & $3 \%$ & $20 \%$ & $32 \%$ & $39 \%$ & \\
\hline 2 Term papers group grade & $15 \%$ & $11 \%$ & $23 \%$ & $29 \%$ & $22 \%$ & \\
\hline 3 Group oral presentation group/individual grade & $7 \%$ & $4 \%$ & $19 \%$ & $31 \%$ & $38 \%$ & \\
\hline 4 Individual work on in-class case-studies & $2 \%$ & $7 \%$ & $27 \%$ & $39 \%$ & $25 \%$ & \\
\hline 5 Work individually on term papers & $2 \%$ & $8 \%$ & $23 \%$ & $35 \%$ & $32 \%$ & \\
\hline 6 Work individually on oral presentations & $7 \%$ & $24 \%$ & $28 \%$ & $28 \%$ & $15 \%$ & \\
\hline 7 Participate in class discussions & $1 \%$ & $5 \%$ & $16 \%$ & $37 \%$ & $42 \%$ & \\
\hline 8 Listening to Lectures by Professors & $5 \%$ & $10 \%$ & $18 \%$ & $28 \%$ & $39 \%$ & \\
\hline 9 Listening to Guest Speakers & $5 \%$ & $12 \%$ & $26 \%$ & $33 \%$ & $24 \%$ & \\
\hline 10 Working on real-life hands -on projects & $1 \%$ & $1 \%$ & $12 \%$ & $19 \%$ & $67 \%$ & \\
\hline 11 Participating in role playing exercises & $8 \%$ & $12 \%$ & $19 \%$ & $28 \%$ & $20 \%$ & $14 \%$ \\
\hline 12 Using computer simulation/games & $3 \%$ & $4 \%$ & $24 \%$ & $30 \%$ & $22 \%$ & $18 \%$ \\
\hline
\end{tabular}


Table 4: continued

\section{Delivery System}

13 PowerPoint

14 Video

15 Lectures

16 Blackboard/Angel course mgt sys

\section{$3 \%$}

$4 \%$

$4 \%$

$3 \%$

$3 \% \quad 18 \%$

$5 \% \quad 23 \%$

$8 \% \quad 26 \%$

$19 \%$

$38 \%$

0

$32 \%$

$33 \%$

$30 \%$

$26 \%$

$41 \%$

\section{Effectiveness Of Assessment}

17 Objective test

18 Essay test

19 Take-home test

20 Term paper

21 Oral Presentations

$\begin{array}{lllll}1 \% & 3 \% & 18 \% & 41 \% & 37 \% \\ 7 \% & 19 \% & 31 \% & 30 \% & 13 \% \\ 1 \% & 4 \% & 11 \% & 33 \% & 52 \% \\ 2 \% & 8 \% & 25 \% & 42 \% & 24 \% \\ 9 \% & 6 \% & 26 \% & 41 \% & 19 \%\end{array}$

Table 5: Perception Variation by Senior Class

Effectiveness Of Learning
1 Working in small groups for in-class problems
2 Term papers group grade
3 Group oral presentation group/individual grade
4 Individual work on in-class case-studies
5 Work individually on term papers
6 Work individually on oral presentations
7 Participate in class discussions
8 Listening to Lectures by Professors
9 Listening to Guest Speakers
10 Working on real-life hands -on projects
11 Participating in role playing exercises
12 Using computer simulation/games

$\underline{\text { NE }}$

NE-N

$\begin{array}{llllll}14 \% & 5 \% & 20 \% & 30 \% & 31 \% & \\ 21 \% & 25 \% & 8 \% & 27 \% & 19 \% & \\ 5 \% & 5 \% & 25 \% & 36 \% & 30 \% & \\ 5 \% & 10 \% & 27 \% & 33 \% & 25 \% & \\ 5 \% & 5 \% & 20 \% & 30 \% & 40 \% & \\ 12 \% & 15 \% & 34 \% & 22 \% & 17 \% & \\ 0 \% & 4 \% & 15 \% & 39 \% & 42 \% & \\ 1 \% & 9 \% & 21 \% & 31 \% & 38 \% & \\ 7 \% & 2 \% & 31 \% & 34 \% & 26 \% & \\ 2 \% & 0 \% & 10 \% & 24 \% & 64 \% & \\ 9 \% & 6 \% & 21 \% & 26 \% & 15 \% & 24 \% \\ 4 \% & 4 \% & 22 \% & 21 \% & 26 \% & 22 \%\end{array}$

\section{Delivery System}

13 PowerPoint

14 Video

15 Lectures

16 Blackboard/Angel course mgt sys

$\begin{array}{lllll}7 \% & 6 \% & 21 \% & 30 \% & 36 \% \\ 5 \% & 2 \% & 19 \% & 39 \% & 36 \% \\ 1 \% & 4 \% & 30 \% & 31 \% & 33 \% \\ 11 \% & 10 \% & 23 \% & 26 \% & 30 \%\end{array}$

\section{Effectiveness Of Assessment}
17 Objective test
18 Essay test
19 Take-home test
20 Term paper
21 Oral Presentations

$\begin{array}{lllll}3 \% & 2 \% & 22 \% & 43 \% & 31 \% \\ 11 \% & 10 \% & 26 \% & 35 \% & 18 \% \\ 3 \% & 2 \% & 16 \% & 31 \% & 48 \% \\ 5 \% & 8 \% & 26 \% & 44 \% & 18 \% \\ 8 \% & 15 \% & 23 \% & 35 \% & 18 \%\end{array}$

\section{OBSERVATION AMONG MAJORS}

Multiple differences surfaced when analyzing the data according to majors. Perhaps the best way to describe the differences is by generalizing what each particular major preferred and disliked.

As reflected in Table 6, accounting, marketing, management, and finance majors all ranked real life, handson projects as its highest preference, while economics majors ranked participating in in-class discussions as their top preference. There was less uniformity among the majors on what was least effective for learning. Working individually on oral presentations and receiving a group grade was the least effective for accounting, management, 
and finance majors. Economics majors ranked participating in role playing the least effective while marketing majors ranked role playing and group term papers with group grade as the worst tool for learning.

Table 6: Perception Variations by Majors

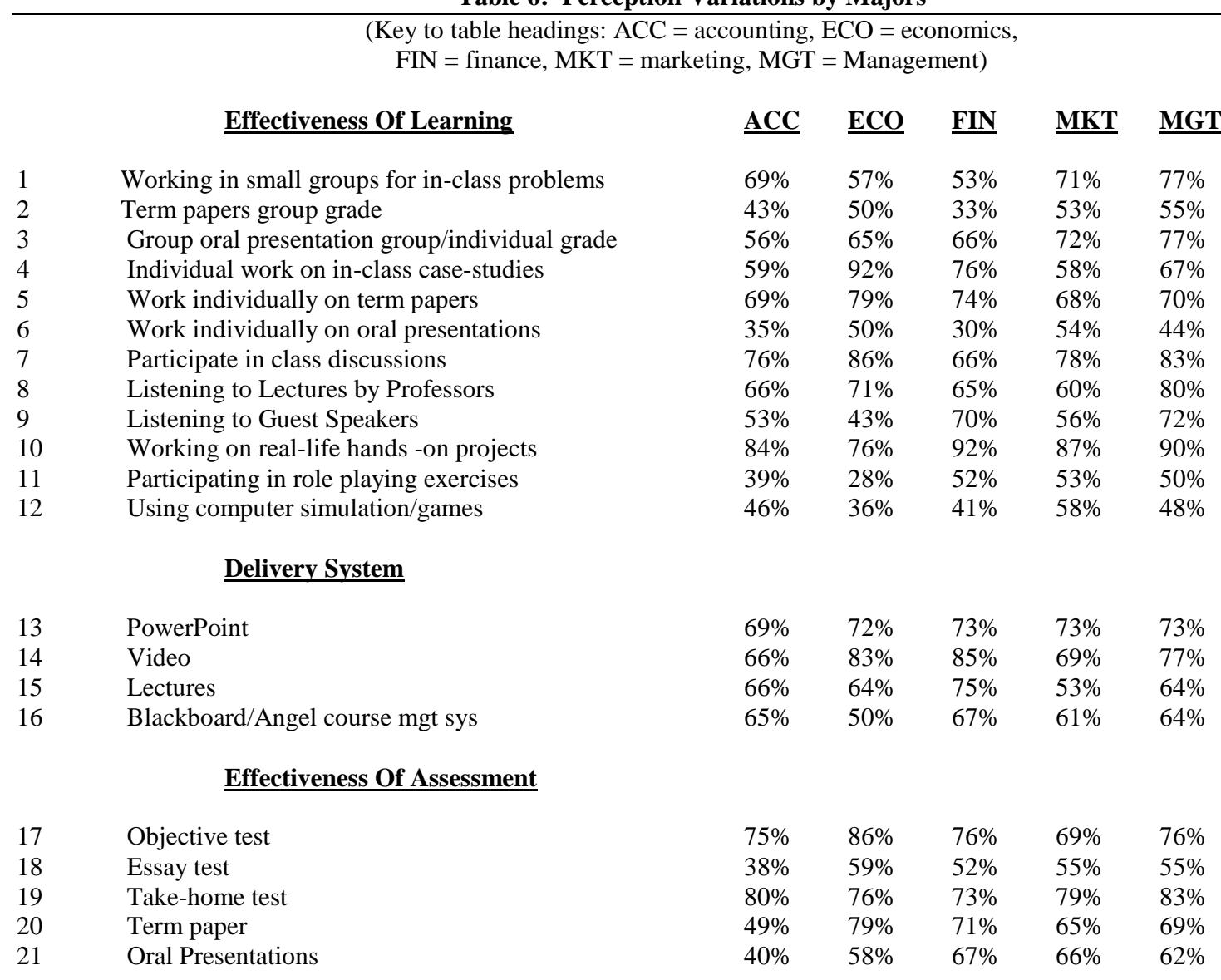

Percentages reflect percentage by major that selected either effective or very effective for corresponding question. Accounting and economics majors ranked role paying as being less effective for their learning than did the other majors. Business schools, relying on input from employers and alumni, have urged professors to have their students work in small groups. While accounting, marketing, and management students report learning effectively in small groups, economics and finance majors are less likely to benefit from them. Regarding the use of guest speakers it appears that finance and management students reap the highest reward from them. All others ranked it as less effective. Lectures by professors were ranked as effective for student learning by all majors; although marketing students ranked this lower than all other majors.

\section{GENDER VARIATIONS}

The data in Table 7 reflects the demographics of those surveyed by major and gender. While the institution does keep data on gender it does not break down the percentages of gender by majors. Based on the survey results, economics and finance majors are overwhelmingly male while marketing and accounting majors are favored by females. In fact, there were 50\% more women marketing majors than men. The only major in the survey that seemed gender neutral was management. 
Table 7: Respondent Demographics by Major and Gender

\begin{tabular}{lrr}
\hline & Male & $\underline{\text { Female }}$ \\
& & $35.1 \%$ \\
Accounting & $29.7 \%$ & $0.6 \%$ \\
Economics & $6.9 \%$ & $3.6 \%$ \\
Finance & $12.2 \%$ & $34.5 \%$ \\
Marketing & $23.2 \%$ & $26.2 \%$ \\
Management & $28.0 \%$ &
\end{tabular}

As shown in Table 8, male and female student responses to their likes and dislikes were generally similar. Males were more accepting of group-graded term papers. They also preferred in-class case studies, individual oral presentations, and using computer simulation/games. Female students had a stronger preference for group-graded oral presentations, and individual term papers. While both were very positive about working on real-life hands-on projects, women ranked this as more effective for learning than men. (Key to table headings: $E=E f f e c t i v e, V E=$ Very Effective.)

Table 8: Perception Variations by Gender

(Key to table headings: $\mathrm{E}=$ effective, $\mathrm{VE}=$ Very Effective)

\section{Effectiveness Of Learning}

1

2

3

4

5

6

7

8

9

10

11

12

13 PowerPoint

$14 \quad$ Video

15 Lectures

16 Blackboard/Angel course mgt sys

\section{$\underline{\text { Delivery System }}$}

\section{$\underline{\text { Male }}$} $\underline{\mathbf{E}}$

$33.2 \%$

$27.7 \%$

$34.6 \%$

$45.9 \%$

$35.3 \%$

$27.2 \%$

$8.2 \%$

$32.5 \%$

$32.3 \%$

$25.3 \%$

$34.3 \%$

$37.1 \%$ $\underline{\text { VE }}$

$36.2 \%$

$26.7 \%$

$30.3 \%$

$23.2 \%$

$32.6 \%$

$20.7 \%$

$20.7 \%$

$41.7 \%$

$34.0 \%$

$27.0 \%$

$60.5 \%$

$22.5 \%$
Female

$\underline{\mathbf{E}} \underline{\mathrm{VE}}$

$33.5 \% \quad 35.9 \%$

$25.3 \% \quad 17.1 \%$

$30.5 \% \quad 39.6 \%$

$30.2 \% \quad 27.3 \%$

$28.4 \% \quad 42.0 \%$

$23.7 \% \quad 12.8$

$33.1 \% \quad 12.8 \%$

$32.6 \% \quad 41.4 \%$

$36.3 \% \quad 37.0 \%$

$21.6 \% \quad 25.0 \%$

$31.3 \% \quad 66.7 \%$

$34.0 \% \quad 24.1 \%$

\section{Effectiveness Of Assessment}

$\begin{array}{ll}17 & \text { Objective test } \\ 18 & \text { Essay test } \\ 19 & \text { Take-home test } \\ 20 & \text { Term paper } \\ 21 & \text { Oral Presentations }\end{array}$

$\begin{array}{ll}41.8 \% & 25.5 \% \\ 39.6 \% & 35.3 \% \\ 36.0 \% & 22.7 \% \\ 34.6 \% & 26.8 \%\end{array}$

$39.9 \%$

$38.6 \%$

$43.6 \% \quad 25.7 \%$

$32.3 \% \quad 33.5 \%$

\section{CONCLUSIONS}

There are clear distinctions among students regarding their preference for learning methods, the best delivery methods, and manner of assessment. Clearly, all students liked working on real-life hands-on projects. These findings duplicate Karns' research results of marketing majors $(1993,2005)$. On the other hand, students 
found oral presentations of little value in their learning or in the assessment of what they learned. Perhaps it is time to revisit the purpose of oral presentations. Does it meet a specific goal of the college? While students may not prefer this learning tool, perhaps it develops a skill that is essential for the business professional. This assumption should be verified.

While some business schools link finance and accounting or finance and economics in the same department, this study reveals that students' perceptions of effective learning are different for each major. Accounting and finance value real-life projects, while economic majors do not. Accounting and economics majors learn from participating in class discussions; however, finance majors ranked class discussions much lower in effectiveness. While accounting students valued small group in-class discussions, finance and economics students ranked its value much lower.

The issue of class times raises interesting issues. Should the prime time slots be reserved for required courses? If retention of majors is an issue, an argument could be made to follow that practice. Students have indicated that they learn best in specific time periods. Utilizing preferred time periods should reap a better retention rate.

The distinctions, by class year, raise some interesting questions that require further study. Freshmen prefer to work in small groups, while seniors are not as inclined. Freshmen prefer PowerPoint, while seniors have a slightly greater preference for guest speakers. Is this because freshmen are not yet acclimated to university life and find comfort in getting a PowerPoint outline and group help on assignments? If so, how else might universities and professors make the transition easier? Reasons for this preference would be instructive. Seniors may prefer to work alone because it provides them a chance to excel and distinguish themselves before entering the workforce. Nearing graduation, they may begin to feel the necessity of performing individually on the job. Again, why they prefer working alone needs to be determined. Seniors preference for guest speakers could be that they can now appreciate the value that these speakers bring to the class or the fact that they are able to frame their own outlines of class material and no longer need PowerPoint to provide the structure.

Going forward, these results have generated many new, unanswered questions that bear further research. Are preferences expressed by students due to the nature of the course or the nature of the student? Do differences between freshmen and seniors reflect a self-selection into a particular field that matches their personalities and preferences? Or do they reflect maturation and move towards a professional attitude? Regarding assessments, why do students prefer take-home tests? Why do they prefer objective tests over essay tests? Is it a preference based on perceived ease or familiarity? What are faculty perceptions of learning and assessments? Where do they coincide and where do they diverge? Finally, do certain learning activities or assessments reflect an essential skill as determined by those practicing in the profession?

Understanding how, why, and when students learn best, the best method of delivery and assessment of learning would provide instructors with a firm foundation for making course delivery and assessment decisions that would enable maximum student learning and utilization of resources.

\section{AUTHOR INFORMATION}

Vincent Agnello is a Professor of Law at Niagara University. As a professor of law he teaches law, ethics courses, legal environment of business and employment law. In the past few years he has become interested in the learning process and the changes in the learning process. This interest has resulted in doing studies in learning and teaching. In addition to his teaching, he has maintained and active practice of law for over twenty years.

Bohdan Pikas is a Professor of Marketing at Niagara University. Professor Pikas has taken an eclectic approach to his publishing activities and has published many papers on a variety of topics. In recent years, Professor Pikas has been very interested in new product development related to digital devices and how students use them in the classroom. This interest led to the study of the learning process in today's student. 
Audrey Agnello is a Professor of Accounting at Niagara County Community College where she teaches accounting. In addition to her teaching duties, Professor Agnello is very active in creating new programs and courses that capitalize on modern teaching methods and delivery software/hardware. Her interest in the students' perception of learning is ongoing.

Anastasia Pikas is an Adjunct Professor of Statistics at Niagara University. In this capacity, she has had opportunity to incorporate the latest software and video devices to her classroom. In doing so, she has evaluated the effectiveness of various lecture delivery methods in a mathematics related course. Her knowledge of the delivery of a quantitative course has been tuned over many years of teaching.

\section{REFERENCES}

1. Betts, S. \& Knaus, R. (2006). Student Perceptions of the Teaching Effectiveness of a management Simulation in a Business Policy and Strategy Course. Proceedings of the Academy of Educational Leadership, 11(1): 3-6.

2. Clarke, I., Flaherty, T. \& Mottner, S. (2001). Student Perceptions of Educational Technology Tools. Journal of Marketing Education, 23(3): 169-177.

3. Duke, C. (2002). Learning Outcomes: Comparing Student Perceptions of Skill Level and Importance. Journal of Marketing Education, 24(3): 203-217.

4. Giordano, J. \& Rochford, R. (2005). Understanding Business Majors' Learning Styles. The Community College Enterprise, 11(2): 21-39.

5. Gottschall, H. \& Garcia-Bayonas, M. (2008). Student Attitudes Towards Group Work Among Undergraduates in Business Administration, Education and Mathematics. Educational Research Quarterly, 32(1): 3-28.

6. James, K., Burke, L. \& Hutchins, H. (2006). Powerful or Pointless? Faculty Versus Student Perceptions of PowerPoint Use in Business Education. Business Communications Quarterly, 69(4): 374-396.

7. Karns, G. (1993). Marketing Student Perceptions of Learning Activities: Structure, Preferences, and Effectiveness. Journal of Marketing Education, 15(1): 3-10.

8. Karns, G. (2005). An Update of Marketing Student Perceptions of Learning Activities: Structure, Preferences, and Effectiveness. Journal of Marketing Education, 27(2): 163-171. 


\section{NOTES}

